RESEARCH ARTICLE

\title{
Class 1 Integron, Sulfonamide and Florfenicol Resistance Genes in Bacteria from Three Unsanitary Landfills, Ibadan, Nigeria
}

\author{
Olawale Olufemi Adelowo and Abolaji Idowu Osuntade \\ Environmental Microbiology and Biotechnology Laboratory, Department of Microbiology, University of Ibadan, Ibadan, \\ Oyo State, Nigeria
}

\begin{abstract}
Objective: Municipal solid waste (MSW) landfills recently emerged as potential reservoirs of antibiotic resistance. However, little is known about the potentials of unsanitary landfill sites which are common in developing countries as reservoir of antibiotic resistance. In this study, we investigated the antibiotic resistance pattern and presence of selected resistance genes in bacteria from three MSW landfills in Ibadan, southwestern Nigeria.
\end{abstract}

Methodology: Fifty six antibiotic- and metal-resistant bacteria isolated from leachate and leachate-contaminated surface and groundwater collected from three MSW landfills in Ibadan, Southwestern Nigeria, were searched for sulfonamides, florfenicol and beta-lactams resistance genes and integrons by PCR.

Results: None of the $27 \beta$-lactamase genes tested was detected in the isolates. sul1, sul2 and floR were however detected in 12 (21.4\%), 2 (3.6\%) and 12 (21.4\%) bacteria species identified as Alcaligenes faecalis, Advenella kashmirensis, Brevundimonas spp. and Ralstonia pickettii. The 12 bacteria carrying sul1/floR gene combination were also positive for class 1 integron. Analysis of the gene cassettes in the variable regions of the class 1 integrons $(>1.5 \mathrm{~kb})$ of the 12 intl1-positive isolates revealed the presence of aadB and unknown genes. The deduced amino acid sequence of the unknown portion of the gene cassettes shared $42-65 \%$ identity with sequences of Class $D \beta-$ lactamase and OXA-2-like protein in the GenBank.

Conclusions: Findings of this study suggest that the landfill ecosystem is a potential site for the evolution of novel resistance genes and are hence important reservoir of antibiotic resistant bacteria. J Microbiol Infect Dis 2019; 9(1): 34-42.

Keywords: Landfill leachate, antibiotic resistance, sul genes, floR, aadB, class $D \beta$-lactamase

\section{INTRODUCTION}

Antibiotic resistance in bacteria is a major threat to human health worldwide [1] and environmental bacteria are increasingly being recognized as important reservoir of clinically relevant antibiotic resistance genes (ARG) [2]. There are increasing concerns about the impact of anthropogenic pollution on environmental reservoirs of antibiotic resistance [2,3] which may increase the possibility of recruiting antibiotic resistance genes into clinical bacteria species from environmental reservoirs of resistance [4]. As a result, attention is turning to potential reservoirs of resistance outside the clinic [5]. Presently, there are concerns that heavy metals, which are one of the commonest environmental pollutants may co-select for antibiotic resistance in environmental bacteria $[6,7]$. Co-selection may occur when genes for antibiotic and metal resistance are located in the same cell in a process called co-resistance or when a single resistance mechanism confers resistance to metal and antibiotics in a process called cross-resistance [8]. Metals enter the environment from industrial activities, agriculture, aquaculture, wastewater and municipal solid waste (MSW) usually dumped in landfills. Landfills represent an important source of metals input into the environment in many developing countries like Nigeria, where solid waste management is often a serious challenge.

Nigeria, with a population of about 160 million people generate about $0.58 \mathrm{~kg}$ of solid waste/person/day [9] which are commonly

Correspondence: Dr. Olawale Olufemi Adelowo, Environmental Microbiology and Biotechnology Laboratory, Department of Microbiology, University of Ibadan, Nigeria 
disposed in unsanitary landfills usually operated at standards below recommendations for public health safety. The wastes are not sorted before disposal, and mixtures of domestic, industrial, agricultural and hospital wastes are commonly co-disposed in the same landfill site. The landfills are also used by surrounding populations for open defecation and discharge of human and animal fecal waste containing high concentrations of pathogenic and potentially pathogenic bacteria species. These conditions make them potential hotspots for the development, proliferation and spread of antibiotic resistance. Once developed, resistance can spread from landfills into human populations through direct contact with the landfill or indirectly via leachate contamination of surrounding soil and aquatic ecosystems, especially where the resistance traits are associated with mobile genetic elements. This risk is particularly high for countries like Nigeria where landfill sites are often reclaimed for residential purposes and people living in close proximity to landfill sites use leachatecontaminated surface and groundwater sources for domestic purposes. There is also a growing population of scavengers who regularly visits urban landfill sites to collect recyclable materials as a means of livelihood.

Some recent studies have reported the incidence of antibiotic resistance in bacteria isolated from landfill leachate in Nigeria [10] and Thailand [11]. Similarly, Wang et al [12], Wu et al [13] and Song et al [14] reported the detection of ARGs in the metagenomic DNA fraction of leachate and refuse from landfill sites in China. Some of these studies have reported a positive correlation between the presence of metals and occurrence of antibiotic resistance genes in the leachate emanating from the investigated landfills pointing to possible co-selection pressure in the landfill ecosystem $[15,16]$. While these studies contributed immensely to establishing landfills as important reservoir of antibiotic resistance, they did not provide information on the taxonomic identity of the bacteria host and/or the genetic context of detected ARG. Further, few of the studies investigated the possible spread of $A R B$ and ARGs into surrounding aquatic ecosystems via leachate contamination.
In this study, bacteria isolated from leachates and leachate-contaminated surface and ground water collected from, or within the vicinity of three unsanitary MSW landfills in Ibadan, southwestern Nigeria were tested for susceptibility to seven antibiotics and for tolerance to Zinc ( $\mathrm{Zn})$, Copper $(\mathrm{Cu})$ and Lead $(\mathrm{Pb})$. The isolated bacteria strains were searched for 31 genes conferring resistance to sulfonamides $(n=3)$, beta-lactams $(n=27)$ and florfenicol $(n=1)$ as well as Class 1, 2 and 3 integrons. Our overall aim is to investigate the potentials of unsanitary landfills as reservoir of antibiotic resistance that can spread to the human population.

\section{METHODS}

\section{Study area}

Ibadan $\left(7^{\circ} 23^{\prime} 47^{\prime \prime} \mathrm{N} 3^{\circ} 55^{\prime} 0^{\prime \prime} \mathrm{E}\right)$ the capital of Oyo State, Nigeria, is the third largest city by population in Nigeria with a population of 3.2 Million inhabitants. As at the time of this study, the city has three functioning unsanitary landfill sites namely Ajakanga, Aba-eku and Awotan established in 1996, 1997 and 1998, and covering approximately 10, 10 and 25 hectare $^{2}$ respectively. The sites are operated by the Ibadan Waste Management Authority. Ajakanga (07¹8' 43"N 0350' 27"E; $165 \mathrm{~m}$ above sea level) is in Oluyole Local Government area of Oyo State while Awotan (07 $27^{\prime}$ 49"N 0350'56"E; $237 \mathrm{~m}$ above sea level), also known as Apete dumpsite, is located in Iddo Local Government Area. Aba-eku (07019'28"N 0359'17"E; $162 \mathrm{~m}$ above sea level), also known as Afofunra, is located at Ona Ara Local government area. Aba-eku dumpsite was scheduled for upgrading to a sanitary landfill in 1998 but the upgrading process is yet to commence as at the time of this study. There is no provision for the collection and treatment of leachate in any of the three dumpsites and the leachate generated from decomposing wastes run freely into surrounding aquatic and soil ecosystems.

\section{Sample collection}

Composited samples of leachate $(n=15)$ were collected from the leachate stream flowing from the three landfills (Ajakanga=AJL, Awotan=AWL, Aba eku=ABL) into sterile $500 \mathrm{ml}$ glass sampling bottles every two weeks from June through 
August 2014. Similarly, leachate-contaminated surface water $(n=10)$ was collected upstream (UPS $=50 \mathrm{~m}$ ) and downstream (DWS=250 m) of the leachate-contaminated stream at Aba-eku, and groundwater samples $(n=25)$ were collected from 2 hand-dug wells at Aba-Eku (W1 and W2, $\mathrm{n}=10$ ) and three hand-dug wells in Awotan (W3, W4 and W5, $n=15$ ). All the sampled wells are within residential houses located about 200 $500 \mathrm{~m}$ from the landfills and serve as sources of domestic water supply for the inhabitants of the buildings. Sample collection from wells was limited to residential houses where access was granted for the purpose of sample collection.

\section{Sample processing}

\section{Physicochemical analysis}

The temperature, $\mathrm{pH}$, total dissolved solids (TDS), electrical conductivity (EC) (Eutech PCSTestr 35 Multi Parameter tester, EutechThermo Scientific, Singapore) and dissolved oxygen (DO) (DO Meter, PDO-520 Model, Lutron Electronics, Taiwan), as well as the concentrations of $\mathrm{Cu}, \mathrm{Zn}, \mathrm{Pb}, \mathrm{Cd}$ and $\mathrm{Cr}$ were determined as described [17]. The metals were selected for analysis either because they are frequently detected in leachates or have been linked with occurrence of antibiotic resistance in the environment [7]. Samples for metal analysis were digested in $6 \mathrm{~N} \mathrm{HNO}_{3}$ before the concentrations of each metal was determined by Atomic Absorption Spectrophotometry (AAS) (ZEEnit 650P, AnalytikJena, Jena, Germany). Values obtained were compared to standards regulating the discharge of effluents [18] and drinking water quality [19] in Nigeria.

\section{Bacteria isolation and determination of total heterotrophic bacteria count (THBC)}

Bacteria were isolated without metal or antibiotic selection on Mueller Hinton Agar (MHA) plates by the surface spread method. Dilutions $\left(10^{-5}\right)$ of leachate and water samples were spread on the surface of MHA plates incubated at $35{ }^{\circ} \mathrm{C}$ overnight for determination of the THBC of the samples and isolation of bacteria. One representative of each morphologically distinct colonies growing on the plates were selected, purified on fresh agar plates and stored in glycerol broth $(15 \%)$ at $-15{ }^{\circ} \mathrm{C}$. All bacterial isolates were subjected to gram staining and biochemical characterization tests. Isolates showing negative gram reactions were selected for further studies of antibiotic resistance and metal tolerance.

\section{Antibiotic susceptibility and metal tolerance testing}

\section{Antibiotic susceptibility}

Isolated bacteria were tested for susceptibility to ertapenem (ETP, $10 \mu \mathrm{g}$ ), cefpodoxime (CPD, 30 $\mu g$ ), ciprofloxacin (CIP, $10 \mu \mathrm{g})$, gentamicin ( $\mathrm{CN}$, $10 \mu \mathrm{g}$ ), tetracycline (TET, $30 \mu \mathrm{g}$ ), florfenicol (FFC, $30 \mu \mathrm{\mu g}$ ) and sulfamethoxazole/ Trimethoprim (SXT, $25 \mu \mathrm{g})\left(\mathrm{OXOID}^{\mathrm{TM}}\right)$ by disc diffusion as described by the Clinical and Laboratory Standards Institute [20]. Zones of growth inhibition around each disc after overnight incubation at $35{ }^{\circ} \mathrm{C}$ were measured and interpreted by the zone diameter interpretive standards of the CLSI [20].

\section{Test of metal tolerance}

Tests of metal tolerance were carried out by spot inoculation on metal-supplemented MHA plates as described by Ünaldi Coral et al [21]. Filter sterilized salts of the metals $(\mathrm{ZnCl}, \mathrm{PbCl}$ and $\mathrm{CuSO}_{4}$ ) were added to cooled $\mathrm{MHA}$ at the following graded concentrations $(\mu \mathrm{g} / \mathrm{ml})$ : 100 , $200,400,600,800,1000,1,100$. The plates were incubated for $48 \mathrm{hrs}$. at $35{ }^{\circ} \mathrm{C}$. The minimum concentration of metals to inhibit bacterial growth after 48 hours was recorded as the minimum inhibitory concentration (MIC).

\section{Statistical analysis}

Pearson's correlation analysis was performed to establish relationships between resistance to heavy metals and antibiotics among the bacteria isolates at 0.05 and 0.01 levels of significance. Data analysis was performed using SPSS 19.0 software (SPSS Inc, Chicago IL).

\section{Ethical approval}

No special ethical or regulatory approval is needed to carry out the research reported in this study.

\section{PCR detection of antibiotic resistance genes and integrons}

Total genomic DNA was extracted from the test bacteria by boiling lysis [22] and the lysates used in PCR to detect antibiotic resistance genes in isolates displaying phenotypic 
resistance to SXT, FFC and the beta-lactams (CPD and ETP) with primers targeting sul1, sul2 and sul3 [23], floR [24], the ESBLs blaTEM, blaSHV, blaCTX-M, blaGES, blaVEB and blaPER; and carbapenemases blaVIM, blaNDM, blaKPC, blalMP, blaSPM, blaAIM and blaDIM [25], oxacillinases blaOXA-1, blaOXA-2, blaOXA-10, bla $O X A-23$, blaOXA-24, bla $O X A-48$, blaOXA-51 and blaOXA-58 and ampC blaCMY1, blaCMY-2, blaACC, blaACT, blaDHA and blaFOX [26] as well as Class 1, 2 and 3 integrons [27]. The variable regions of class 1 integrons and the promoters were amplified with previously described primers and protocols [2729]. All PCR reactions were carried out in $25 \mu \mathrm{l}$ volumes with DreamTaq Green PCR Master Mix (2X) (Thermo Fisher Scientific). Selected amplicons of each detected gene $(1.2 \%$ agarose gels) were sequenced (Macrogen Inc, Amsterdam Netherlands). The taxonomic identities of all isolates positive for at least one of the resistance genes tested were confirmed by amplification and sequencing of the $16 \mathrm{~S}$ rRNA genes.

\section{RESULTS}

\section{Leachate and leachate-contaminated surface and groundwater characteristics}

The chemical and microbiological characteristics of the leachate and leachate-contaminated surface and groundwater samples are shown in Table 1. The temperature, $\mathrm{pH}$, TDS and EC were lowest in W3 while the lowest value of DO was measure in AJL. All the metals tested were detected in the leachates and water samples. The level of $\mathrm{Cu}$ ranged from 0.03 (W1) to 0.27 $\mathrm{mg} / \mathrm{l}$ (AWL), Zn from 0.39 (UPS) to $0.76 \mathrm{mg} / \mathrm{l}$ (AWL), Pb from 0.12 (W3) to $0.47 \mathrm{mg} / \mathrm{l}(\mathrm{ABL})$, Cd from 0.03 (W3) to $0.21 \mathrm{mg} / \mathrm{l}(\mathrm{AWL})$ and $\mathrm{Cr}$ from $0.17(\mathrm{~W} 4)$ to $0.57 \mathrm{mg} / \mathrm{l}(\mathrm{ABL})$. The $\mathrm{pH}$ of the leachates and surface water are within recommended standards by NESREA [18], while all the well water samples have $\mathrm{pH}$ below recommended values for drinking water [19]. Similarly, all the leachate samples as well as water samples from wells W1, W2, and W4 have TDS above the maximum recommended for discharged effluent and drinking water. The DO in two samples of leachate (AJL and $A B L$ ) are below the minimum $(4.0 \mathrm{mg} / \mathrm{l})$ recommended by NESREA [18]. The NESREA regulation did not specify any standard for EC, however, all the well water samples have values of EC lower than that set for drinking water by SON [19]. The concentrations of $\mathrm{Cu}, \mathrm{Zn}, \mathrm{Pb}$ and $\mathrm{Cd}$ in all the leachate samples and $\mathrm{Cr}$ concentration in $\mathrm{ABL}$ and $\mathrm{AWL}$, as well as the concentrations of $\mathrm{Pb}$, $\mathrm{Cd}$ and $\mathrm{Cr}$ in all the wells are all above recommended standard for discharged effluents and drinking water in Nigeria.

\section{Bacteria isolates and their susceptibility to antibiotics and heavy metals}

Forty six (46) out of 56 (82\%) Gram negative bacteria selected for tests of antibiotic resistance and metal tolerance showed varying degree of co-resistance to metal and antibiotics. These were identified as members of the Phylum Proteobacteria namely: Ralstonia (12), Alcaligenes (11), Pseudomonas (9), Enterobacter (3), Stenotrophomonas (3), Proteus (2), Citrobacter (2), Erwinia (1) Advenella (1) Brevundimonas (1) and Raoultella (1). Results of susceptibility testing showed that $34(74 \%)$ of the isolates were resistant to CPD while $23(50 \%), 21(45.6 \%), 19(41 \%), 18(39 \%)$, $6(13 \%)$ and $6(13 \%)$ respectively showed resistance to SXT, ETP, FFC, TET, CN and CIP. The metal MIC among these isolates raged between $200 \mu \mathrm{g} / \mathrm{mL}$ and $\geq 1100 \mu \mathrm{g} / \mathrm{mL}$ (Table 2). Overall, 34 isolates (74\%) showed resistance to more than one antibiotics with multiple antibiotic resistance (MAR) index ranging between 0.29 and 1.0. One isolate, $A$. faecalis AP31 from AWL was resistant to all the antibiotics tested with MAR index of 1.0 and metal MICCu/Pb/Zn of $300, \quad 1100$ and $300 \mu \mathrm{g} / \mathrm{ml}$ respectively. Resistance to $\mathrm{Cu}$ and Zinc showed a positive correlation with resistance to some of the tested antibiotics $(p<0.05$ and $p<0.01)$. Cu resistance correlated positively with resistance to ertapenem (0.813) and florfenicol (0.855) while $\mathrm{Zn}$ resistance correlated positively with resistance to ciprofloxacin (0.678), gentamicin (0.899) and tetracycline (0.735).

\section{Detection of antibiotic resistance genes and integrons}

sul1, sul2 and floR conferring resistance to sulfonamides and florfenicol were detected in 14 (25\%) bacteria species identified by $16 \mathrm{~S}$ rRNA gene sequencing as $A$. faecalis $(n=11)$, Advenella kashmirensis, Brevundimonas sp. and Ralstonia pickettii. The detected floR shared 91- 
$96 \%$ sequence identity with $f l o R$ in uncultured bacterium clone $\mathrm{CH}-0406$ (KU548555.1) and Stenotophomonas maltophilia strain GZP-Sm1 (KM649682.1). sul1 and floR were detected in 12 isolates all showing phenotypic resistance to SXT and FFC suggesting a co-selection of the two genes in the bacteria isolates. sul2 was detected in 3 isolates with the gene occurring together with sul1/floR in one isolate and singly in two isolates identified as $A$. kashmirensis from $\mathrm{ABL}$ and Brevundimonas sp. from W5 (Table 2). Class 2 and 3 integrons were not detected in any of the isolates, but class 1 integron was detected in the 12 isolates carrying the sul1/floR gene combination.

Sequencing of the 1.5-1.7 $\mathrm{kb}$ amplicons obtained with primers targeting the variable regions of detected class 1 integrons showed that in all the 12 isolates, a portion of the sequences (about 600 bp) shared 90-99\% sequence identity with $a a d B$ on the class 1 integrons of Corynebacterium aspernum (AJ871915.1) and Pseudomonas aeruginosa strains $\quad 19 \quad$ (HM367614.1), 29081162 (JF742758.1), 4019-1 (KF468743.1) and P5 (JF412714.1). This gene probably formed the basis of resistance to gentamicin observed in some of the isolates. The remaining portion of the sequence showed no significant similarity with any known gene in the GenBank. Thus, to decipher the possible identities of these regions, they were used in a BLASTX search in the GenBank Database. In all the isolates, the translated nucleotide sequences shared $42-65 \%$ amino acid identity with Class $D \beta$-lactamase of Synechococcus sp. NKBG15041c (WP024546971.1), uncultured bacterium (AMP47147.1) or Colwellia psychrerythraea (WP033083257.1), and OXA-2-like protein of an uncultured bacterium (ALG03676.1).

To further confirm this observation, we next searched for putative ORFs in the sequences using orf-finder (https://www.ncbi.nlm.nih.gov/orffinder/) and confirmed the identities of detected ORFs by

\section{SmartBLAST}

(https://blast.ncbi.nlm.nih.gov/smartblast/smartBI ast.cgi). Two ORFs were identified in two isolates from Awotan leachate ( $A$. faecalis AP12) and well ( $A$. faecalis APW412) showing significant alignment with beta-lactamases while only one of such ORF was identified for the remaining ten isolates. ORF3 (AP12, 55aa) and ORF8 (APW312, 38aa) as well as the single ORF identified in the sequences of the remaining 10 isolates (55-86aa) shared $58-66 \%$ sequence identities with class $D \beta$-lactamase of Synechocystis sp. PCC6803 (WP070097971.1), and $36-50 \%$ identities with class $D$ carbapenemhydrolyzing $\beta$-lactamase BlaA of Shewanella oneidensis MR-1 (NP716468.1). ORF8 (AP12, 52aa) and ORF2 (APW312, 55aa) shared 50\% and $67 \%$ identities with class $D \beta$-lactamase of Synechocystis sp. PCC6803 (WP070097971.1). Interestingly, eleven and one of the isolates gave positive amplification signals with primers targeting bla ${ }_{O X A-48}$ and bla OXA-23 respectively. bla ${ }_{O X A-48}$ and bla OXA-23 are carbapenem hydrolyzing Class D $\beta$-lactamase. However, sequencing of the amplicons showed they were non-specific products with the deduced amino acid sequence of the OXA-23 detected in $C$. ferundii AB18 sharing $78 \%$ identity with an MFS transporter protein of Caulobacter sp. Root 656 with accession number WP057182697.1. In addition, seven of the eleven isolates showed resistance to ETP suggesting a possible role for the ORFs in carbapenem resistance. However, further experiments would be required to confirm the role of the genes in carbapenem resistance. The gene cassettes in all the isolates are under the control of weak promoters PcW which was associated with inactive second promoters $\mathrm{P} 2$ in two isolates from $A B L$ and $A W L$ respectively (Table 2). Weak promoters (PcW) usually have strong excision activity [29] which can promote the excision and rapid dissemination of the gene cassettes carried on this integron to other bacteria of the landfill ecosystems. 
Table 1. Physicochemical and microbiological characteristics of leachates and leachate-contaminated surface and groundwater samples.

\begin{tabular}{|c|c|c|c|c|c|c|c|c|c|c|c|c|c|}
\hline \multicolumn{3}{|c|}{ Sampling Points } & \multicolumn{5}{|c|}{ Physicochemical parameters } & \multicolumn{5}{|c|}{ Heavy metals (mg/l) } & \multirow{2}{*}{$\begin{array}{c}\text { Mean }^{c} \\
\text { THBC } \\
\text { (cfu/ml) } \\
\times 10^{8}\end{array}$} \\
\hline Sites & Coordinates & $\begin{array}{l}\text { Elevation } \\
\qquad(\mathrm{m})\end{array}$ & $\begin{array}{l}\text { Temp } \\
\left({ }^{\circ} \mathrm{C}\right)\end{array}$ & $\mathrm{pH}$ & $\begin{array}{l}\text { TDS } \\
(\mathrm{mg} / \mathrm{l})\end{array}$ & $\begin{array}{c}E C \\
(\mu \mathrm{s} / \mathrm{cm})\end{array}$ & $\begin{array}{c}\mathrm{DO} \\
(\mathrm{mg} / \mathrm{l})\end{array}$ & $\mathrm{Cu}$ & $\mathrm{Zn}$ & $\mathrm{Pb}$ & Cd & $\mathrm{Cr}$ & \\
\hline AJL & $\begin{array}{l}\text { N07 18'43" } \\
\text { E03 } 50^{\prime} 27^{\prime \prime}\end{array}$ & 165 & 29.6 & 6.85 & 2200 & 3120 & 2.7 & 0.04 & 0.44 & 0.46 & 0.18 & 0.15 & $2.72 \pm 1.3$ \\
\hline$A B L$ & $\begin{array}{l}\text { N07 } 19 ' 28^{\prime \prime} \\
\text { E03 } 59^{\prime} 17^{\prime \prime}\end{array}$ & 162 & 29.5 & 7.15 & 3080 & 4530 & 3.3 & 0.31 & 0.66 & 0.47 & 0.19 & 0.57 & $2.08 \pm 0.74$ \\
\hline AWL & $\begin{array}{l}\text { N07 } 27^{\prime} 49^{\prime \prime} \\
\text { E03 } 50^{\prime} 56^{\prime \prime}\end{array}$ & 237 & 26.0 & 7.65 & 1670 & 2350 & 16.9 & 0.27 & 0.76 & 0.41 & 0.21 & 0.53 & $1.63 \pm 0.4$ \\
\hline UPS & $\begin{array}{l}\text { N07 } 199^{\prime} 33^{\prime \prime} \\
\text { E03 } 59^{\prime} 22^{\prime \prime}\end{array}$ & 149 & 29.7 & 6.95 & 1380 & 937 & 8.5 & 0.22 & 0.39 & 0.27 & 0.17 & 0.51 & $2.25 \pm 1.0$ \\
\hline DWS & $\begin{array}{l}\text { N07 } 19 ' 32^{\prime \prime} \\
\text { E03 } 59^{\prime} 27^{\prime \prime}\end{array}$ & 147 & 29.1 & 6.92 & 366 & 517 & 8.6 & 0.07 & 0.49 & 0.23 & 0.08 & 0.24 & $4.67 \pm 1.6$ \\
\hline $\mathrm{W} 1^{\mathrm{a}}$ & $\begin{array}{l}\text { N07 } 19 ' 31^{\prime \prime} \\
\text { E03 } 59^{\prime} 22^{\prime \prime}\end{array}$ & 151 & 30.5 & 5.98 & 647 & 924 & 8.8 & 0.03 & 0.54 & 0.16 & 0.06 & 0.21 & $2.19 \pm 1.8$ \\
\hline $\mathrm{W}^{\mathrm{a}}$ & $\begin{array}{l}\text { N07 } 19 ' 29^{\prime \prime} \\
\text { E03 } 59^{\prime} 19^{\prime \prime}\end{array}$ & 156 & 29.6 & 5.97 & 685 & 977 & 8.9 & 0.05 & 0.65 & 0.19 & 0.17 & 0.26 & $2.80 \pm 1.8$ \\
\hline$w 3^{b}$ & $\begin{array}{l}\mathrm{N} 07^{\circ} 27^{\prime} 40^{\prime \prime} \\
\mathrm{E} 03^{\circ} 50^{\prime} 60^{\prime \prime}\end{array}$ & 218 & 24.5 & 4.98 & 352 & 497 & 8.0 & 0.12 & 0.45 & 0.12 & 0.03 & 0.25 & $2.38 \pm 0.6$ \\
\hline$W 4^{b}$ & $\begin{array}{l}\text { N07 } 27^{\prime} 42^{\prime \prime} \\
\text { E03 } 50^{\prime} 52^{\prime \prime}\end{array}$ & 220 & 27.3 & 5.22 & 681 & 960 & 72.5 & 0.14 & 0.42 & 0.22 & 0.07 & 0.17 & $2.0 \pm 1.2$ \\
\hline$W 5^{b}$ & $\begin{array}{l}\text { N07 } 27^{\prime} 42^{\prime \prime} \\
\text { E03 } 50^{\circ} 51^{\prime}\end{array}$ & 218 & 27.1 & 5.75 & 462 & 651 & 77.5 & 0.15 & 0.53 & 0.20 & 0.12 & 0.18 & $2.88 \pm 1.1$ \\
\hline \multicolumn{14}{|c|}{$\begin{array}{l}\text { AJL=Ajakanga Leachate, } A B L=A b a \text { eku Leachate, } A W L=A w o t a n \text { Leachate, UPS=river water collected upstream of landfill site, } \\
\text { DWS=river water collected downstream of landfill site, W1-5=Wells } 1,2,3,4,5 \text {, TDS=total dissolved solids, EC=Electrical } \\
\text { conductivity, DO=dissolved oxygen, THBC=total heterotrophic bacteria count, a=W1-2 are located at Aba Eku Land fill site, } b=W 3-5 \\
\text { are located at Awotan Landfill site, } C=T H B C \text { is a mean of values determined for all sampling times for each sample }\end{array}$} \\
\hline \multirow{2}{*}{\multicolumn{2}{|c|}{ Isolates }} & \multirow[b]{2}{*}{ Source } & \multirow{2}{*}{$\begin{array}{l}\text { MAR } \\
\text { Index }\end{array}$} & \multirow{2}{*}{\multicolumn{3}{|c|}{$\begin{array}{l}\text { Phenotypic pattern of } \\
\text { Antibiotic resistance }\end{array}$}} & \multicolumn{3}{|c|}{ Metal MIC $(\mu \mathrm{g} / \mathrm{ml})$} & \multirow{2}{*}{\multicolumn{3}{|c|}{$\begin{array}{c}\text { Detected } \\
\text { Resistance Genes }\end{array}$}} & \multirow{2}{*}{$\begin{array}{l}\text { Promoter } \\
\text { Type }\end{array}$} \\
\hline & & & & & & & Metal & $\operatorname{MIC}(\mu$ & g/mI) & & & & \\
\hline \multicolumn{2}{|c|}{$\begin{array}{l}\text { Advenella kashmirensis } \\
\text { AB17b }\end{array}$} & $A B L$ & 0.14 & & SXT & & 800 & 1100 & 1100 & & sul2 & & \\
\hline \multicolumn{2}{|c|}{$\begin{array}{l}\text { Brevundimonas sp. } \\
\text { APW }_{5} 10\end{array}$} & W5 & 0.14 & & SXT & & 300 & 700 & 1100 & & sul2 & & \\
\hline \multicolumn{2}{|c|}{ Ralstonia pickettii AJ21 } & AJL & 0.14 & & FFC & & 600 & 700 & 1100 & & & & \\
\hline \multicolumn{2}{|c|}{ R. solanacearum AP29 } & AWL & 0.14 & & TET & & 300 & 600 & 1100 & & & & \\
\hline \multicolumn{2}{|c|}{ R. pickettii APW 51} & W5 & 0.14 & & TET & & 500 & 500 & 1100 & & & & \\
\hline R. pic & ettii AP3 & AWL & 0.14 & & CPD & & 600 & 500 & 1100 & & & & \\
\hline $\begin{array}{l}\text { Pseuc } \\
\text { AP25 }\end{array}$ & monas taetrolens & AWL & 0.14 & & CPD & & 300 & 200 & 1100 & & & & \\
\hline P. alc & igenes AB24 & $A B L$ & 0.14 & & CPD & & 600 & 300 & 1100 & & & & \\
\hline P. alc & igenes $\mathrm{AB} 13$ & $A B L$ & 0.14 & & TET & & 500 & 600 & 1100 & & & & \\
\hline P. me & docina AP5 & AWL & 0.14 & & CPD & & 600 & 1100 & 1100 & & & & \\
\hline R. sol & nacearum AB10 & $A B L$ & 0.14 & & TET & & 600 & 900 & 1100 & & & & \\
\hline $\begin{array}{l}\text { Steno } \\
\text { maltor }\end{array}$ & $\begin{array}{l}\text { phomonas } \\
\text { iilia AP23 }\end{array}$ & AWL & 0.14 & & CPD & & 300 & 1100 & 1100 & & & & \\
\hline Citrob & cter freundii AB18 & $A B L$ & 0.29 & & ETP, C & & 600 & 900 & 1100 & & & & \\
\hline
\end{tabular}




\begin{tabular}{|c|c|c|c|c|c|c|c|c|}
\hline R. solanacearum $\mathrm{AB} 6$ & $\mathrm{ABL}$ & 0.29 & SXT, TET & 500 & 500 & 1100 & & \\
\hline Erwinia mallotivora AJ17 & AJL & 0.29 & CPD, CIP & 500 & 300 & 1100 & & \\
\hline P. jinjuensis UP20 & UPS & 0.29 & ETP, CPD & 300 & 200 & 1100 & & \\
\hline $\begin{array}{l}\text { Enterobacter cloacae } \\
\text { ABW }_{2} 19\end{array}$ & W2 & 0.29 & SXT, TET & 500 & 300 & 1100 & & \\
\hline P. fluorescens AP6 & AWL & 0.29 & CPD, TET & 500 & 1100 & 1100 & & \\
\hline P. taetrolens AP21 & AWL & 0.29 & ETP, CPD & 500 & 600 & 1100 & & \\
\hline $\begin{array}{l}\text { Alcaligenes faecalis } \\
\text { AP12 }\end{array}$ & AWL & 0.29 & CPD, SXT & 900 & 900 & 1100 & floR, Int/1/sul1 & PcW \\
\hline A. faecalis AJ11 & AJL & 0.43 & CPD, FFC, SXT & 600 & 600 & 1100 & floR, Intl1/sul1 & PcW \\
\hline A. faecalis UP22 & UPS & 0.43 & CPD, FFC, SXT & 600 & 1100 & 1100 & floR, Int/1/sul1 & $\mathrm{PcW}$ \\
\hline A. faecalis DS13 & DWS & 0.43 & CPD, FFC, SXT & 800 & 1100 & 1100 & floR, Intl1/sul1 & $\mathrm{PcW}$ \\
\hline A. faecalis $\mathrm{ABW}_{1} 16$ & W1 & 0.43 & ETP, CPD, SXT & 600 & 300 & 1100 & floR, Intl1/sul1 & $\mathrm{PcW}$ \\
\hline Ent. aerogenes AP12 & AWL & 0.43 & ETP, CPD, FFC & 600 & 600 & 1100 & & \\
\hline S. maltophilia DS16 & DWS & 0.43 & ETP, CPD, FFC & 300 & 600 & 1100 & & \\
\hline S. maltophilia $\mathrm{APW}_{3} 1$ & W3 & 0.43 & CPD, SXT, TET & 300 & 700 & 1100 & & \\
\hline R. solanacearum UP19 & UPS & 0.43 & ETP, CPD, FFC & 400 & 300 & 1100 & & \\
\hline R. solanacearum $\mathrm{AB} 8$ & $\mathrm{ABL}$ & 0.43 & CPD, TET, CN & 600 & 500 & 1100 & & \\
\hline Proteus vulgaris $\mathrm{AB} 9$ & $\mathrm{ABL}$ & 0.43 & CPD, TET, CN & 500 & 500 & 1100 & & \\
\hline R. pickettii $\mathrm{ABW}_{1} 6$ & W1 & 0.43 & FFC, SXT, CN & 500 & 300 & 1100 & & \\
\hline Roultella planticola DS12 & DWS & 0.43 & ETP, CPD, FFC & 1100 & 1100 & 1100 & & \\
\hline A. faecalis DS18 & DWS & 0.57 & ETP, CPD, FFC, SXT & 300 & 300 & 1100 & floR, Int/1/sul1 & $\mathrm{PcW}$ \\
\hline Ent. cloacae $\mathrm{APW}_{3} 3$ & W3 & 0.57 & ETP, CPD, FFC, SXT & 900 & 300 & 1100 & & \\
\hline P. stutzeri UP13 & UPS & 0.57 & ETP, CPD, SXT, TET & 600 & 1100 & 1100 & & \\
\hline R. pickettii $\mathrm{ABW}_{1} 17$ & W1 & 0.57 & ETP, CPD, FFC, SXT & 600 & 300 & 1100 & & \\
\hline C. freundii $\mathrm{AB} 14$ & $\mathrm{ABL}$ & 0.57 & ETP, CPD, FFC, CIP & 500 & 500 & 1100 & & \\
\hline R. pickettii $\mathrm{AB} 17$ & $\mathrm{ABL}$ & 0.71 & ETP, CPD, FFC, SXT, TET & 800 & 1100 & 1100 & floR, Intl1/sul1 & PcW-P2 \\
\hline A. faecalis $\mathrm{ABW}_{1} 22$ & W1 & 0.71 & ETP, CPD, FFC, SXT, CIP & 200 & 600 & 1100 & floR, Intl1/sul1 & PcW \\
\hline A. faecalis $\mathrm{APW}_{3} 16$ & W3 & 0.71 & ETP, CPD, FFC, SXT, TET & 500 & 1100 & 1100 & floR, Intl1/sul1 & $\mathrm{PcW}$ \\
\hline P. vulgaris $\mathrm{APW}_{3} 14$ & W3 & 0.71 & ETP, CPD, FFC, SXT, TET & 700 & 1100 & 1100 & & \\
\hline R. pickettii UP15 & UPS & 0.71 & ETP, CPD, SXT, TET, CN & 700 & 1100 & 1100 & & \\
\hline A. faecalis $\mathrm{ABW}_{2} 16$ & W2 & 0.86 & $\begin{array}{c}\text { ETP, CPD, FFC, SXT, CIP, } \\
\text { TET }\end{array}$ & 600 & 300 & 1100 & floR, Int/1/sul1 & PcW \\
\hline A. faecalis $\mathrm{APW}_{4} 12$ & W4 & 0.86 & $\begin{array}{c}\text { ETP, CPD, FFC, SXT, CIP, } \\
\text { TET }\end{array}$ & 600 & 200 & 1100 & $\begin{array}{l}\text { floR, sul2, } \\
\text { Intl1/sul1 }\end{array}$ & PcW \\
\hline A. faecalis AP31 & AWL & 1.00 & $\begin{array}{c}\text { ETP, CPD, FFC, SXT, CIP, } \\
\text { TET, CN }\end{array}$ & 300 & 1100 & 300 & floR, Intl1/sul1 & PcW-P2 \\
\hline
\end{tabular}

$\mathrm{MIC}=$ Minimum Inhibitory concentration, $\mathrm{ABL}=\mathrm{Aba-eku}$ leachate, $\mathrm{W} 1$ and $\mathrm{W} 2=$ Wells at Aba-eku landfill, UPS=Water sample collected upstream, DWS=Water samples collected downstream at Aba-eku, AWL=Awotan leachate, W3, W4, W5=Wells at Awotan landfill, $A J L=A j a k a n g a$ leachate, ETP=Ertapenem, CPD=Cefpodoxime, FFC=Florfenicol, SXT=Sulphamethoxazole/Trimethoprim, $\mathrm{CIP}=$ Ciprofloxacin; TET=Tetracycline, $\mathrm{CN}=$ Gentamicin; $\mathrm{Zn}=\mathrm{Zinc}, \mathrm{Pb}=\mathrm{lead}$, $\mathrm{Cu}=\mathrm{Copper}$

\section{DISCUSSION}

Recent studies have raised concerns on the important role played by MSW landfills as reservoir of antibiotic resistance. However, only few of these studies emanated from subSaharan Africa where MSW landfills are the commonest method of solid waste management. In this study we detected sul1, sul2, floR as well as class 1 integron carrying $a a d B$ as a gene cassette in bacteria isolated from leachates and leachate contaminated water from three unsanitary MSW landfills in Ibadan, Nigeria. The bacteria were identified as members of the Phylum Proteobacteria and have previously been reported in landfill leachates in different parts of the world [30-32]. This is worrisome as some of the bacteria species such as Alcaligenes, Pseudomonas, Stenotrophomonas and Raoultella are important opportunistic pathogens and reservoir of novel antibiotic resistance genes and their isolation in household wells used for drinking and other 
domestic purposes by the surrounding population of the waste dumpsites is a risk to public health. None of the tested resistance genes was detected in 32 isolates (69.6\%) despite the presence of phenotypic resistance to various antibiotics suggesting that the observed resistance was mediated by novel resistance genes or by non-specific resistance mechanisms such as reduced outer membrane permeability or multidrug resistance efflux pumps [33].

sul1/floR/intl1 occurred together in 12 bacteria isolated from leachates (ABL, AWL, AJL) well water (W1, W2, W3, W4) and stream water (UPS, DWS) collected from the three sampling sites suggesting a cross contamination of the surrounding surface and groundwater by ARBs from the landfill sites and a possible cooccurrence of these genes in the isolates. Further, as the three sampling sites do not share ecological connectivity, it is likely the cooccurrence of these genes is linked to bacteria taxonomic identity rather than conditions predominating in the landfill ecosystem. Usually, floR-carrying bacteria exhibit high levels of simultaneous resistance to other antibiotics with resistance to potentiated sulfonamides among the most frequent $[34,35]$. In conclusion, we detected sul1, sul2 and floR in 14 bacteria species isolated from three MSW landfills and surrounding aquatic ecosystem in Ibadan, southwestern Nigeria. We could not detect any of the $27 \beta$-lactams resistance genes tested for in PCR despite the presence of phenotypic resistance to $\beta$-lactams, but an unknown portion of the variable region of class 1 integrons found in 12 isolates carrying the sul1/floR combination show significant alignment with class $D \quad \beta$ lactamases suggesting that the landfill ecosystem may be a reservoir of previously unknown ARGs which can potentially be transmitted from this environmental reservoir to the human population. Further experiments would however be needed to confirm this as well as investigate potential transmission of these antibiotic resistant bacteria into the human population. It is also important to put measures in place to properly manage leachate from landfill sites for public health safety.

\section{ACKNOWLEDGMENTS}

Declaration of Conflicting Interests: The authors declare that they have no conflict of interest.
Funding source: The authors received no third party funding for this study.

\section{REFERENCES}

1. Pruden A, Joakim-Larsson DG, Amézquita A, et al. Management options for reducing the release of antibiotics and antibiotic resistance genes to the environment. Environ Health Perspect 2013; 121:878-885.

2. D'Costa VM, McGrann KM, Hughes DW, Wright GD. Sampling the antibiotic resistome. Science 2006; 311:374-377.

3. Finley RL, Collignon P, Joakim-Larsson DG, et al. The scourge of antibiotic resistance and the important role of the environment. Clin Infect Dis 2013; 57:704710.

4. Knapp CW, McCluskey SM, Singh BK, Campbell CD, Hudson G, Graham DW. Basal antibiotic resistance gene abundances correlate with metal and geochemical conditions in Scottish soils. PLoS One 2011; 6:e27300.

5. Canton R. Antibiotic resistance genes from the environment: a perspective through newly identified antibiotic resistance mechanisms in the clinical setting. Clin Microbiol Infect 2009; 15 Suppl 1:20-25.

6. Baker-Austin C, Wright MS, Stepanauskas R, McArthur JV. Co-selection of antibiotic and metal resistance. Trends Microbiol 2006; 14:176-182.

7. Seiler C, Berendonk TU. Heavy metal driven coselection of antibiotic resistance in soil and water bodies impacted by agriculture and aquaculture. Front Microbiol 2012; 3:1-10.

8. Pal C, Asiani K, Arya S, Rensing C, Stekel DJ, Joakim Larsson DG, Hobman JL. Metal resistance and its association with antibiotic resistance. Advances in Microbial Physiology 2017; 70:261-296.

9. Aruekwe A, Eggen T, Mödder M. Solid waste deposits as a significant source of contaminants of emerging concern to the aquatic and terrestrial environments- a developing country case study from Owerri, Nigeria. Sci Total Environ 2012; 438:94-102.

10. Efuntoye MO, Bakare AA, Sowunmi AA. Virulence factors and antibiotic resistance in Staphylococcus aureus and Clostridium perfringens from landfill leachate. Afr J Microbiol Res 2011; 5:3994-3997.

11. Threedeach $\mathrm{S}$, Chiemchaisri $\mathrm{W}$, Watanabe $\mathrm{T}$, Chiemchaisri C, Honda R, Yamamoto K. Antibiotic resistance of Escherichia coli in leachates from municipal solid waste landfills: comparison between semi-anaerobic and anaerobic operations. Bioresour Technol 2012; 113:253-258.

12. Wang Y, Tang W, Qiao J, Song L. Occurrence and prevalence of antibiotic resistance in landfill leachate. Environ Sci Pollut Res 2015; 22:1252512533. 
13. Wu D, Huang Z, Yang K, Graham D, Xie B. Relationships between antibiotics and antibiotic resistance gene levels in municipal solid waste leachates in Shanghai, China. Environ Sci Technol 2015; 49:4122-4128.

14. Song L, Li L, Yang S, et al. Sulfamethoxazole, tetracycline, oxytetracycline and related antibiotic resistance genes in a large-scale landfill, China. Sci Total Environ 2016; 551-552:9-15.

15. Yu Z, He P, Shao L, Zhang H, Lü F. Cooccurrence of mobile genetic elements and antibiotic resistance genes in municipal solid waste landfill leachates: A preliminary insight into the role of landfill age. Water Research 2016; 106:583-592.

16. Zhang $X-H, X u Y-B, H e X-L$, et al. occurrence of antibiotic resistance genes in landfill leachate treatment plant and its effluent-receiving soil and surface water. Environmental Pollution 2016; 218:1255-1261.

17. American Public Health Association (APHA) (1998) Standard methods for the examination of water and wastewater. $20^{\text {th }}$ Ed. American public Health Association Inc. Washington D.C.

18. National Environmental Standards and Regulations Enforcement Agency (NESREA) (2011) National Environmental (surface and groundwater quality control) Regulations. NESREA, Abuja, Nigeria.

19. Standards Organisation of Nigeria (SON) (2007) National Standards for Drinking Water Quality (NSDWQ).

20. CLSI. Performance standards for antimicrobial susceptibility testing; Twenty Fourth Informational Supplement (M100-S24). CLSI, 2014; Wayne, PA. USA.

21. Ünaldi Coral MN, Korkmaz H, Arikan B, Coral, G. Plasmid mediated heavy metal resistances in Enterobacter spp. Isolated from Sofulu landfill in Adana, Turkey. Ann Microbiol 2005; 55(3):175-179.

22. Peirano G, Agerso Y, Aarestrup FM, Falavina dos Reis EM, Rodirgues DP. Occurrence of integrons and antimicrobial resistance genes among Salmonella enterica from Brazil. J Antimicrob Chemother 2006; 58:305-309.

23. Wang N, Yang X, Jiao S, Zhang J, Ye B, Gao S. Sulfonamide-resistant bacteria and their resistance genes in soils fertilized with manures from Jiangsu Province, Southeastern China. PLoS One 2014; 9(11), e112626.

24. Adelowo OO, Fagade OE, Agerso YA. Antibiotic resistance and resistance genes in Escherichia coli from poultry farms, southwest Nigeria. J Infect Dev Ctries 2014; 8:1103-1112.

25. Trung NT, Hien TTT, Huyen TTT, et al. Simple multiplex PCR assays to detect common pathogens and associated genes encoding for acquired extended spectrum beta-lactamases (ESBL) or carbapenemases from surgical site specimens in Vietnam. Ann Clin Microbiol Antimicrob 2015; 14:23.

26. Voets GM, Fluit AC, Scharringa J, Stuart JC, Leverstein-van Hall MA. A set of multiplex PCRs for genotypic detection of extended-spectrum $\beta$ lactamases, carbapenemases, plasmid-mediated AmpC $\beta$-lactamases and OXA $\beta$-lactamases. Int $\mathrm{J}$ Antimicrob Agents 2011; 37:356-359.

27. Machado $E$, Canton $R$, Baquero $F$, et al. Integron content of extended-spectrum- $\beta$-lactamase-producing Escherichia coli strains over 12 years in a single hospital in Madrid, Spain. Antimicrob Agents Chemother 2005; 49(5):1823-1829.

28. Vinué L, Jove T, Torres C, Ploy MC. Diversity of class 1 integron gene cassette $\mathrm{Pc}$ promoter variants in clinical Escherichia coli strains and description of a new P2 promoter variant. Int J Antimicrob Agents 2011; 38:526-529.

29. Jové T, Da Re S, Denis F, Mazel D, Ploy MC. Inverse correlation between promoter strength and excision activity in class 1 Integrons. PLOS Genet 2010; 6(1): e1000793.

30. Huang L-N, Zhou H, Zhu S, Qu L-H. Phylogenetic diversity of bacteria in the leachate of a full-scale recirculating landfill. FEMS Microbiol Ecol 2004; 50:175-183.

31. Huang L-N, Zhu S, Zhou H, Qu L-H. Molecular phylogenetic diversity of bacteria associated with the leachate of a closed municipal solid waste landfill. FEMS Microbiol Lett 2005; 242:297-303.

32. Stamps BW, Lyles CN, Suflita JM, et al. Municipal solid waste landfills harbor distinct microbiomes. Front Microbiol 2016; 7:534. doi: 10.3389/fmicb.2016.00534

33. Allen SE, Boerlin P, Janecko N, et al. Antibiotic resistance in generic Escherichia coli isolates from wild small mammals living in swine farm, residential landfill, and natural environments in Southern Ontario, Canada. Appl Environ Microbiol 2011; 77:882-888.

34. Doublet B, Carattoli A, Whichard JM, et al. Plasmid-mediated florfenicol and ceftriaxone resistance encoded by the floR and blaCMY-2 genes in Salmonella enterica serovars Typhimurium and Newport isolated in the United States. FEMS Microbiol Lett 2004; 233:301-305.

35. Fernández-Alarcón C, Miranda CD, Singer RS, et al. Detection of the floR gene in a diversity of florfenicol resistant Gram-negative bacilli from freshwater salmon farms in Chile. Zoonoses Public Health 2010; 57:181-188. 